\title{
Early and late results of the Nuss operation for pectus excavatum - a single institution experience
}

\author{
Krystian Pawlak, Paweł Zieliński, Piotr Gabryel, Bartłomiej Gałęcki, Wojciech Dyszkiewicz \\ Department of Thoracic Surgery, K. Marcinkowski University of Medical Sciences, Poznan, Poland \\ Kardiochirurgia i Torakochirurgia Polska 2013; 10 (4): 364-368
}

\begin{abstract}
Objective: The purpose of this study was to evaluate the results of operative treatment of pectus excavatum using the Nuss method, with particular emphasis on the surgical technique used.

Material and methods: Between 2002 and 2010, 622 patients (mean age 18.2) underwent surgical correction for pectus excavatum. One Nuss bar was implanted in 317 patients, two plates in 296, and 3 in the remaining nine patients. Metal bars were removed after $2.5-3$ years.

Results: Good and very good corrective effect of the Nuss procedure was achieved in 593 (95.3\%) patients. There was no mortality in the early postoperative period. Transient and minor complications occurred in 213 (34.24\%) patients - the most frequent were pneumothorax and pleural effusion (22,5\%). An asymmetric funnel chest deformity, a complex deformity, reoperation after previously performed corrective surgery, operative time exceeding $60 \mathrm{~min}$, age above 18 years, more than one implanted corrective plate and gender had significant influences on the occurrence of complications in the postoperative period.

Conclusions:

1. The Nuss minimal invasive procedure is very effective and provides very good long-term results in the treatment of pectus excavatum.

2. The use of video-thoracoscopic control during insertion of implanted bars may prevent potential damage to the mediastinal organs.

3. In patients below 18 years old the number of postoperative complications is significantly lower $(p=0.0025)$.

Key words: Pectus excavatum, Nuss procedure, postoperative complications
\end{abstract}

\section{Streszczenie}

Wstęp: Obecnie małoinwazyjna metoda Nussa jest powszechnie uznanym sposobem chirurgicznego leczenia klatki piersiowej lejkowatej.

Celem pracy była ocena wyników leczenia operacyjnego klatki piersiowej lejkowatej metodą Nussa, ze szczególnym uwzględnieniem stosowanej techniki chirurgicznej.

Materiat i metody: Od 2002 r. do 2010 r. u 622 pacjentów (średnia wieku 18,2 roku) wykonano zabieg operacyjny metodą Nussa z powodu klatki piersiowej lejkowatej. Jedną płytkę korekcyjną wszczepiono u 317 pacjentów, dwie płytki u 296, a trzy u pozostałych 9 pacjentów. Implanty usuwano po 2,5-3 latach. Wyniki: Dobre i bardzo dobre wyniki korekcji metodą Nussa uzyskano u 593 (95,3\%) pacjentów. Nie obserwowano zgonów we wczesnym okresie pooperacyjnym. Przemijające i niegroźne dla życia powikłania wystąpiły w 213 (34,24\%) przypadkach - najczęściej była to odma i płyn w opłucnej (22,5\%). Asymetryczne i złożone deformacje klatki piersiowej lejkowatej, reoperacja po uprzednio wykonanym zabiegu korekcyjnym, czas operacji powyżej $60 \mathrm{~min}$, wiek powyżej 18 lat, wszczepiona więcej niż jedna płytka korekcyjna oraz płeć męska miały znaczący wpływ na występowanie powikłań w okresie pooperacyjnym.

Wnioski:

1. Małoinwazyjna metoda Nussa zapewnia bardzo dobre i długotrwałe wyniki w leczeniu klatki piersiowej lejkowatej.

2. Kontrola wideotorakoskopowa podczas implantacji płytek korekcyjnych może zapobiec ewentualnemu uszkodzeniu narządów śródpiersia.

3. U pacjentów poniżej 18. roku życia liczba powikłań jest znacznie niższa $(p=0,0025)$.

Słowa kluczowe: klatka lejkowata, operacja Nussa, powikłania pooperacyjne. 


\section{Introduction}

Funnel chest is the most common congenital deformity of the anterior chest wall. Its frequency is estimated at approximately $1 / 150-1000$ births. Very often this defect is detected in teenagers because of negative psychosocial effects. Pectus excavatum also can cause various ailments including chest pain, decreased exercise tolerance and cardiac arrhythmias. Currently, surgical treatment of this defect is mainly performed for cosmetic reasons. The development of surgical methods of treating this deformation began with the Ravitch operation in 1949. This procedure involves subperichondrial resection of the deformed cartilages, cuneiform osteotomy of the cortex and suturing through the bone to maintain the new shape [1]. However, this operation was characterized by considerable invasiveness and high relapse rates [2]. Ultimately, in 1998 Donald Nuss introduced a technique that is minimally invasive. This changed the opinion regarding the treatment of funnel chest deformity [3]. His method is now widely accepted as safe and effective $[4,5]$.

The purpose of this study was to evaluate the results of the Nuss method in the treatment of pectus excavatum.

\section{Material and methods}

Between 2002 and 2010 in the Department of Thoracic Surgery, Poznań University of Medical Sciences, 622 patients underwent a surgical correction for pectus excavatum. The patients' ages ranged from 7 to 49 years (mean $18.2 \pm 5.7)$. There were 129 (20.7\%) females and 493 (79.3\%) males. The majority of patients (93.2\%) had a typical funnel shaped chest; in others, there was a complex defect called pectus carinatum-excavatum. Most deformations (402 patients, 64.6\%) were symmetrical while in the remaining 220 (35.4\%) they were asymmetrical. Moreover, in 73 patients $(11.7 \%)$ flat and wide deformities were observed, and in 27 patients (4.3\%), the depression covered the entire length of the sternum. In the vast majority of patients $(93.9 \%)$ there was a primary defect, but in $6.1 \%$ the deformity was secondary to previous, ineffective operations. The severity of the chest deformity was evaluated by measuring the distance from the top of the sternal depression to the level of the chest, according to the anthropometric measurements proposed by Rebeis et al. [6]. When the depression was $<2 \mathrm{~cm}$ the deformity was classified as small (0.8\%), between 2 and $3 \mathrm{~cm}$ as medium (18.3\%), between 3 and $5 \mathrm{~cm}$ as large (58.4\%), and $>5 \mathrm{~cm}$ as a huge defect (22.5\%).

In 283 (45.5\%) patients there were various ailments: decreased exercise tolerance $(42.0 \%)$, chest pain $(8.2 \%)$ and palpitations $(0.5 \%)$. Chronic comorbidities were present in $5.6 \%$ of the respondents, the most frequent being asthma in $12(2.0 \%)$ patients, mitral valve insufficiency in $5(0.8 \%)$, and arterial hypertension in 3 (0.3\%).

The routine preoperative preparation included basic laboratory tests (blood cell count and biochemical parameters), a chest X-ray in posterior-anterior $(p-a)$ and lateral projections, spirometry and an electrocardiogram. In se- lected cases, particularly in those patients with previous chest corrective surgery, computed tomography was carried out to assess the magnitude of the deformation. In patients with a history of cardiac events echocardiography was performed.

Surgery was performed under general anesthesia using a single endotracheal tube. In addition epidural anesthesia, with a constant infusion of $0.25 \%$ bupivacaine, was routinely used and was maintained in the early postoperative period. Appropriately modeled corrective stainless metal bars (produced by $\mathrm{BHH}$ Mikromed Sp.) were introduced through two symmetrical small cuts in the middle axillary line according to the Nuss procedure. The bars were placed retrosternally under the guidance of videothoracoscopy. The length of implants used in the operations ranged from 260 to $420 \mathrm{~mm}$. Depending on the severity and type of deformity, one bar was implanted in 317 patients, two plates in 296, while in the remaining 9 patients three metal bars were used to obtain satisfactory correction. In the case of an asymmetric defect corrective bars were bent according to the shape of the deformation as described by Park et al. [14]. A short steel stabilizer to prevent rotation of the metal bar was inserted near one end of the implant. This stabilizer and both ends of the corrective bar were strongly attached to the corresponding ribs by non-absorbable sutures. The final location of the implants was assessed on both sides of the pleural cavities by videothoracoscopy. Additionally, in the last 221 operated patients a no. 24-28 F chest tube was routinely inserted into the right pleural cavity in the mid axillary line, and was connected to vacuum suction. It was usually removed on the second postoperative day. Metal bars were maintained for 2.5-3 years. They were then removed under general anesthesia with access via the operative scar. Both ends of each metal strut were folded back and the implants were then removed from the chest.

The patients were followed up at 1, 3, 6 and 12 months after surgery, and then after 1 month and one year after the removal of the metal bars. During these inspections chest $p-a$ and lateral radiographs were taken and in doubtful cases an ultrasound examination of the chest was used to diagnose the presence of pleural fluid.

Statistical analyses were performed using the Statistic 8.0 and Med Calc software programs. The $\chi^{2}$ test was used, and a level of $p<0.05$ was regarded as statistically significant.

\section{Results}

In the majority of patients (54.5\%) the clinical course was asymptomatic.

The corrective effect of the Nuss procedure was assessed as good or very good in 593 (95.3\%) respondents.

There were no deaths in the early 30 -day postoperative period related to the surgical treatment. One patient died one year after Nuss surgery from a car accident.

Transient and minor complications in the early postoperative period occurred in 213 (34.24\%) patients.

Of these, pneumothorax was the most frequent (22.5\%). This included 46 (7.4\%) patients who were routinely sub- 
jected to postoperative unilateral drainage and 94 (15.1\%) cases without pleural drainage. There was no statistically significant difference in the occurrence of postoperative pneumothorax between groups. In 41 patients a lack of lung re-expansion or of pleural effusion was the indication for pleural re-drainage. In 99 patients without pleural drainage, conservative treatment was enough to resolve the pneumothorax.

Hydrothorax was observed in 46 (7.4\%) patients during the postoperative period, including 17 (2.7\%) patients in whom a chest tube was used routinely, and in 30 (4.8\%) patients without drainage. However, there was no statistically significant difference between these two groups.

Haemothorax was present in 5 patients. One of them required hemostasis using VATS, another had additional pleural drainage and, in the last 2 patients, only pleural puncture and subsequent blood transfusion were needed.

Clinically significant postoperative rotation of the metal strut through 80-90 degrees was observed in 16 patients (2.6\%) - 3 with one implanted bar and 13 with two bars (Fig. 1). In 4 patients, where the implant had rotated more than 90 degrees it was removed immediately after radiological confirmation of this complication. The other 8 patients underwent a re-correction, using the same bar repositioned to the correct angle. The remaining 4 patients with rotations of less then 90 degrees were subjected to routine follow-up until the planned removal of the implants.

Fourteen $(2.3 \%)$ patients underwent redo-surgery because of incomplete correction. In 3 cases bar transposition was the cause of recurrence of deformity. Nine patients underwent corrective surgery between 1 month and 4 years

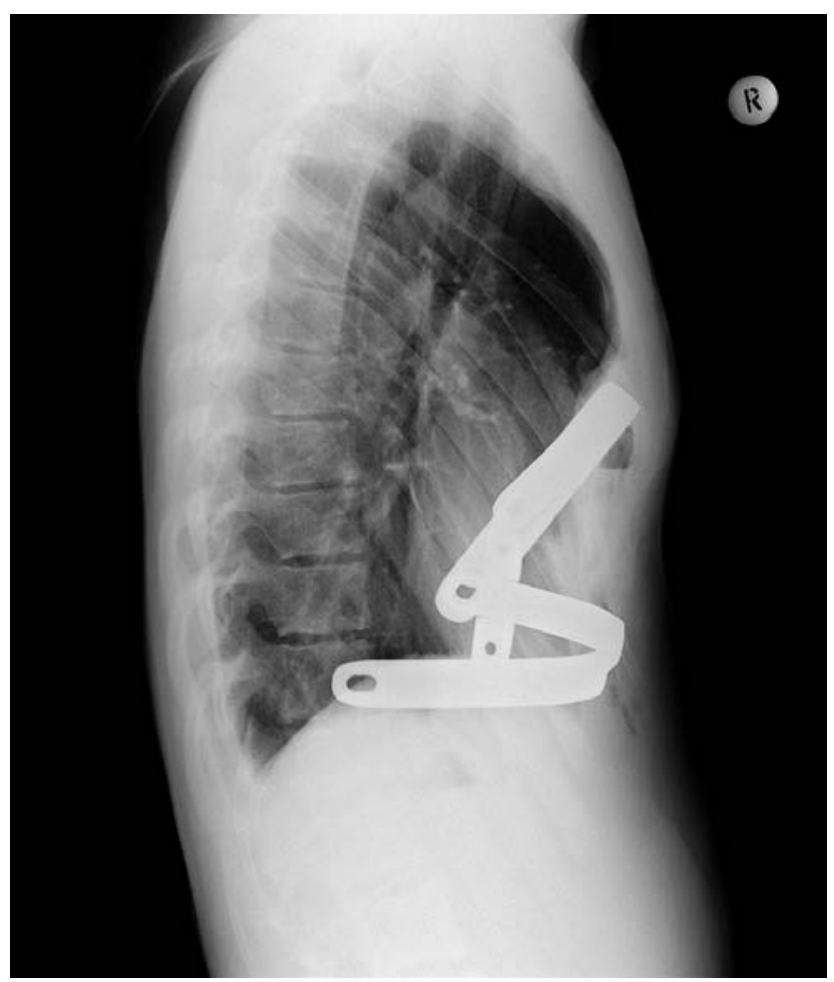

Fig. 1. Rotation of the superior bar after the original surgery. In the other 2 patients a redooperation was required.

One patient in whom pleural empyema was clinically diagnosed one month after the Nuss procedure underwent thoracotomy and pleural drainage.

Severe and prolonged postoperative chest pain occurred in 14 (2.3\%) patients after the Nuss operation. In one of them the implanted bar had to be removed 8 months after the initial surgery. The others did not require additional intervention, and the pain subsided after conservative treatment.

Fever, unrelated to clinical symptoms of infection, was observed postoperatively in 10 patients. In all these cases, the body temperature normalized within several days after antibiotic therapy and the removal of pleural fluid.

Among other complications of minor importance the most frequent were an air leak requiring reoperation and chest pain. Serious, life-threatening hemorrhage occurred in 1 patient during removal of implants as the result of bar rotation [16].

The total number of re-operations for various reasons was 28.

To date, correction bars have been removed in 333 patients on time, and treatment was completed after clinical check-up, usually one year after the removal of the implants.

The postoperative effect of correction by the Nuss method was assessed as good or very good in 592 (95.2\%) patients, satisfactory in 27 (4.3\%), and inadequate in 3 patients (0.5\%).

The statistical analysis revealed that most complications in the early postoperative period occurred in patients above 18 years old, with an asymmetric, or previously corrected funnel chest deformity. Table I shows all statistically significant factors contributing to the early postoperative complications.

\section{Discussion}

Although the number of reports concerning non-operative treatment for pectus excavatum is increasing [7, 8], the minimally invasive Nuss procedure still remains the safest and most popular treatment for this type of congenital deformity $[4,5]$. In the literature there are many reports describing the use of this procedure, but only a few are based on a statistically large enough sample $[4,5]$. We analyzed the results of treatment in a large group of 622 patients operated on in one institution. This enabled us to evalu-

Table I. Significance of pre-operative factors determining the occurrence of postoperative complications as determined by $\chi^{2}$ test

\begin{tabular}{lc} 
Factor & Significance $[p]$ \\
male patients & 0.0368 \\
\hline age over 18 years & 0.0025 \\
\hline complex (mixed) deformity & 0.0400 \\
\hline secondary deformity (redo surgery) & 0.0095 \\
\hline asymmetrical deformity & 0.0060 \\
\hline operative time > 60 min & 0.0011 \\
\hline more than one metal bar implanted & 0.0135 \\
\hline
\end{tabular}


ate the whole process - from the moment of diagnosis to the final, long-term results $[4,5,9]$.

One of the conditions for effective treatment of congenital deformities of the chest is the proper choice of time for surgery. The majority of authors advocate corrective surgery between 12 and 16 years old $[2,10]$. Some believe that the best results can be achieved in patients less than 10 years old, in whom chest flexibility is subjected to modification, and the incidence of early postoperative complications is low [11, 13, 21]. In this study we found no statistically significant differences in the final results in relation to age. However, it seems that any satisfactory correction in the youngest group of patients is short-lived, because of the dynamic growth spurt in the teenage period. On the other hand, we have found that operations performed in patients over 18 years old are associated with a higher risk of postoperative complications. The results of the correction however are more stable and unchanged after growth. In our opinion, the best candidates for surgery by the Nuss procedure would be those patients who have just finished growing at the time of the planned bar removal. Nevertheless, we also observed very good cosmetic results after the Nuss procedure in older patients and it is difficult to determine the upper age limit for this form of corrective surgery $[5,12,14]$.

In the literature there are only a few reports of fatal complications resulting from heart or vascular injuries [15-18]. In our material there were no deaths in the early postoperative period. Only one of our patients experienced life-threatening complications during bar removal when perforation of the ascending aorta occurred due to rotation of the correction bar [16]. Rotation of the metal bar may also cause an injury to the lower lobe, as was described by Leonhardt et al. [17]. Of the 5 patients in whom hemothorax was diagnosed during the early postoperative period in our series, 1 required videothoracoscopic intervention to stop bleeding. In the remaining 4 , conservative treatment such as drainage, pleural puncture or blood transfusion was sufficient. In our opinion, the use of videothoracoscopy plays an important role in prevention of serious complications, as was previously pointed out by other authors $[9,19]$. Acquiring more experience in Nuss procedures over the years, we are of the opinion that the use of bilateral VATS makes this procedure more safe, preventing potential injuries to the heart and vessels.

Overall, early and late postoperative complications occurred in $34 \%$ of the patients but were mild and transient. In the literature, the occurrence of postoperative complications ranged widely from 1 to $73 \%[5,9,14,20]$.

In our patients the most frequent complications were pneumothorax (22.5\%) and pleural effusion (7.4\%), which, according to Castellani et al., may occur in response to the presence of the foreign body thereby resembling the so-called "post-pericardial syndrome" [18]. In the literature, the incidence of pneumothorax and pleural effusion is estimated as ranging from 1 to $5 \%$, and from 1 to $16.7 \%$, respectively $[4,14,18,20]$. In most of our patients pneu- mothorax and pleural effusion were of a limited extent and either conservative treatment or a single puncture of the pleural cavity was sufficient to treat the patients. These complications occurred in patients with and without postoperative drainage. However, our opinion is that routine chest tube insertion is advisable after Nuss surgery, as it improves postoperative surveillance and safety.

One of the most important factors in the correction of deformity is stable and permanent location of the corrective bars. Their displacement in the transverse plane is rare and, according to many authors, occurs in only $1.7-2.4 \%$ of cases $[18,20]$. In our study, this complication occurred in $2.6 \%$ of patients, being the cause of a life-threatening perforation of the wall of the ascending aorta in 1 patient [16]. Since that event we have fixed the corrective bars with a single- or double-sided stabilizer plate and by stitching the bar ends to the ribs. Similar observations have led other authors to abandon the ineffective method of fixation of the metal bars to the fascia of chest wall muscles [12].

Several of our patients showed signs of fever but without other typical inflammation markers (low CRP). These symptoms resolved after several days of conservative treatment and may have resulted from hypersensitivity to elements in the steel. None of these patients required removal of the implants and the symptoms resolved after a few days. Hypersensitivity to components of the correction bar may also manifest itself in the occurrence of pleural effusion and some patients may require puncture or drainage of the pleural space.

A good cosmetic effect was achieved in over $95 \%$ of our patients treated by the Nuss method. The effect was not achieved in patients with significantly asymmetrical deformities and those older than 18 years. Most of the postoperative complications were associated with asymmetric and complex deformities requiring a longer surgical procedure and use of two or more bar implants [22]. Other factors increasing the risk of postoperative complications were redo-surgery and patient's age over 18 years. Many of our observations are consistent with those of other authors who emphasize the importance of these factors for the occurrence of postoperative complications $[4,9,12,18,21]$.

\section{Conclusions}

1. The Nuss minimally invasive procedure is very effective and provides very good long-term results in the treatment of pectus excavatum.

2. The use of videothoracoscopic control during implantation of the metal bars may prevent potential damage to the mediastinal organs.

3. In patients below 18 years old the number of postoperative complications is significantly lower $(p=0.0025)$.

\section{Acknowledgment}

The expert linguistic assistance of Prof. Geoffrey Shaw is gratefully acknowledged. 


\section{References}

1. Ravitch MM. The Operative Treatment of Pectus Excavatum. Ann Surg 1949; 129: 429-444.

2. Ellis DG, Snyder CL, Mann CM. The 're-do' chest wall deformity correction. J Pediatr Surg 1997; 32: 1267-1271.

3. Nuss D, Kelly RE Jr, Croitoru DP, Katz ME. A 10-year review of a minimally invasive technique for the correction of pectus excavatum. Pediatr Surg 1998; 33: 545-552.

4. Pilegaard HK, Licht PB. Early results following the Nuss operation for pectus excavatum - a single-institution experience of 383 patients. Interact Cardiovasc Thorac Surg 2008; 7: 54-57.

5. Kelly RE, Goretsky MJ, Obermeyer R, Kuhn MA, Redlinger R, Haney TS, Moskowitz A, Nuss D. Twenty-one years of experience with minimally invasive repair of pectus excavatum by the Nuss procedure in 1215 patients. Ann Surg 2010; 252: 1072-1081.

6. Rebeis EB, Campos JR, Fernandez A, Moreira LF, Jatene FB. Anthropometric index for Pectus excavatum. Clinics (Sao Paulo) 2007; 62: 599-606.

7. Haecker FM, Mayr J. The vacuum bell for treatment of pectus excavatum: an alternative to surgical correction? Eur J Cardiothorac Surg 2006; 29: 557-561.

8. Harrison MR, Estefan-Ventura D, Fechter R, Moran AM Jr, Christensen D. Magnetic mini-mover procedure for pectus excavatum: I. Development, design, and simulations for feasibility and safety. J Pediatr Surg 2007; 42: 81-85.

9. Cheng YL, Lee SC, Huang TW, Wu CT. Efficacy and safety of modified bilateral thoracoscopy-assisted Nuss procedure in adult patients with pectus excavatum. Eur J Cardiothorac Surg 2008; 34: 1057-1061.

10. Fonkalsrud EW. Current management of pectus excavatum. World J Surg 2003; 27: 502-508.

11. Robicsek F, Watts LT. Surgical correction of pectus excavatum. How did we get here? Where are we going? Thorac Cardiovasc Surg 2011; 59: 5-14.

12. Pilegaard HK. Extending the use of Nuss procedure in patients older than 30 years. Eur J Cardiothorac Surg 2011; 40: 334-337.
13. Ohno K, Morotomi Y, Ueda M, Yamada H, Shiokawa C, Nakaoka T, Tsujimoto K, Nakahira M, Moriuchi T, Harumoto K, Yoshida T. Comparison of the Nuss procedure for pectus excavatum by age and uncommon complications. City Med J 2003; 49: 71-76.

14. Park HJ, Lee SY, Lee CS, Youm W, Lee KR. The Nuss procedure for pectus excavatum: evolution of techniques and early results on 322 patients. Ann Thorac Surg 2004; 77: 289-295.

15. Gips H, Zaitsev K, Hiss J. Cardiac perforation by a pectus bar after surgical correction of pectus excavatum: case report and review of the literature. Pediatr Surg Int 2008; 24: 617-620.

16. Jemielity M, Pawlak K, Piwkowski C, Dyszkiewicz W. Life-threatening aortic hemorrhage during pectus bar removal. Ann Thorac Surg 2011; 91: 593-595.

17. Leonhardt J, Kübler JF, Feiter J, Ure BM, Petersen C. Complications of the minimally invasive repair of pectus excavatum. J Pediatr Surg 2005; 40: e7-9.

18. Castellani C, Schalamon J, Saxena AK, Höellwarth ME. Early complications of the Nuss procedure for pectus excavatum: a prospective study. Pediatr Surg Int 2008; 24: 659-666.

19. Hendrickson RJ, Bensard DD, Janik JS, Partrick DA. Efficacy of left thoracoscopy and blunt mediastinal dissection during the Nuss procedure for pectus excavatum. J Pediatr Surg 2005; 40: 1312-1314.

20. Park HJ, Lee SY, Lee CS. Complications associated with the Nuss procedure: analysis of risk factors and suggested measures for prevention of complications. J Pediatr Surg 2004; 39: 391-395.

21. Kim do JJ, Hwang JJ, Lee MK, Lee DY, Paik HC. Analysis of the Nuss procedure for pectus excavatum in different age groups. Ann Thorac Surg 2005; 80: 1073-1077.

22. Korlacki W, Grabowski A, Dzielicki J. Metoda Nussa w leczeniu deformacji asymetrycznych i mieszanych klatki piersiowej. Kardiol Pol 2011; 8: 354-360. 